\title{
SELECTION OF COWPEA GENOTYPES FOR MATO GROSSO DO SUL VIA GGE BIPLOT AND LINEAR REGRESSION
}

\author{
SELEÇÃO DE GENÓTIPOS DE FEIJÃO-CAUPI PARA MATO GROSSO DO SUL VIA \\ GGE BIPLOT E REGRESSÃO LINEAR
}

\section{Adriano dos SANTOS ${ }^{1}$; Gessi CECCON² ; Erina Vitório RODRIGUES ${ }^{3}$; Paulo Eduardo TEODORO ${ }^{4}$; Agenor Martinho CORREA ${ }^{5}$; Francisco Eduardo TORRES ${ }^{5}$, Rita de Cássia Félix ALVAREZ ${ }^{4}$}

1. Universidade Estadual do Norte Fluminense Darcy Ribeiro, Campos dos Goytacazes, RJ, Brazil; 2. Embrapa Agropecuária Oeste Dourados, MS, Brazil; 3. Embrapa Agroenergia, Brasíla, DF, Brasil; 4. Universidade Federal do Mato Grosso do Sul, Chapadão do Sul, MS, Brasil eduteodoro@ hotmail.com; 5. Universidade Estadual de Mato Grosso do Sul, Aquidauana, MS, Brazil.

\begin{abstract}
The aim of this study was to investigate the association between GGE Biplot and Eberhart and Russell methodologies and to select cowpea genotypes that meet both high grain yield, adaptability and stability for Mato Grosso do Sul environments. The trials were carried out from February to July of 2010, 2011 and 2012 in the municipalities of Dourados, Aquidauana and Chapadão do Sul. The trials in Chapadão do Sul were conducted only in the years 2010 and 2011, totaling eight environments. After detecting significant GE interaction, adaptability and phenotypic stability of cowpea genotypes were analyzed by GGE Biplot and linear regression methods. Eberhart and Russell and GGE biplot methodologies discriminate differently the best cowpea genotypes and it can be used in a complementary way. MNCO1-649F-2-11 and MNCO2-675-4-9 genotypes are the closest to the ideal in terms of high grain yield and phenotypic stability, being so suitable for cultivation in the state of Mato Grosso do Sul.
\end{abstract}

KEYWORDS: Multivariate analysis. Genotype x environment interaction. Vigna unguiculata.

\section{INTRODUCTION}

Cowpea [Vigna unguiculata (L.) Walp.] is an important low-cost protein source for human food in the North and Northeast regions of Brazil, being the states of Ceará, Piauí and Mato Grosso the largest Brazilian producers of this crop (NUNES et al., 2014). In the state of Mato Grosso do Sul, its cultivation is predominantly done in small areas, especially those from the Northeast farmers, who have settled in federal enclaves in the state and in areas belonging to indigenous communities (SANTOS et al., 2014; BARROSO et al., 2016).

Given the great cowpea growth differential, which currently covers three Brazilian regions, it is extremely important to investigate the magnitude of genotypes $x$ environments (GE) interaction in order to choose the best selection strategy and recommendation for cultivars. In this sense, some studies to select upright and prostrate cowpea genotypes superior in adaptability and stability have been conducted. Several methods have been used, among them the classic Eberhart and Russel (1966) based on linear regression have been widely used (ROCHA et al., 2007; BARROS et al., 2013; NUNES et al., 2014; TORRES et al., 2016).

However, there are recent methodologies that adequately explain the principal effects (genotype and environment) and its interaction, such as GGE Biplot analysis, proposed as a graph able to interpret GE interaction in the SREG model (YAN et al., 2000). This analysis considers only that the GE and genotype $(\mathrm{G})$ effects are relevant in assessing cultivars. The graph axes are the first two principal components of multivariate analysis, assuming the environment effects as fixed. Thus, the yield changes are due only to $G$ and GE effects (MIRANDA et al., 2009).

Recently, Eberhart and Russel (1966) and GGE Biplot methodologies have been employed separately for investigating the GE interaction in several crops, but there are no reports on its joint utilization for cowpea. The aim of this study was to investigate the association Eberhart and Russel (1966) and GGE Biplot methodologies and to select cowpea genotypes that simultaneously combine high yield, stability and adaptability to environments of Mato Grosso do Sul.

\section{MATERIAL AND METHODS}

Trials were performed from February to July in the years 2010, 2011 and 2012 in the state of Mato Grosso do Sul. The evaluation environments consisted of combining site and year: Aquidauana, 2010, 2011 and 2012 (AQ10, AQ11 and AQ12, respectively), whose coordinates are $20^{\circ} 27^{\prime} \mathrm{S}$ and $55^{\circ} 40^{\prime} \mathrm{W}$, with altitude of $187 \mathrm{~m}$; Dourados, 2010, 2011 and 2012 (DS10, DS11 and DS12, respectively), situated under the coordinates $18^{\circ} 46^{\prime} \mathrm{S}$ and $52^{\circ} 37^{\prime} \mathrm{W}$, with altitude of $806 \mathrm{~m}$; and Chapadão do Sul, 2010 and 2011 (CS10 and CS11, 
respectively), located under the coordinates $22^{\circ} 16^{\prime} \mathrm{S}$ and $54^{\circ} 49^{\prime} \mathrm{W}$, with altitude of $407 \mathrm{~m}$, totaling eight environments. Table 1 shows the soil and climate characteristics in the regions.

Table 1. Soil and climate characteristics of each environment where 20 cowpea genotypes were evaluated.

\begin{tabular}{cccccc}
\hline Environment & Bioma & Soil & Climate* & $\begin{array}{c}\text { Average } \\
\text { Temperature }\left({ }^{\circ} \mathrm{C}\right) * *\end{array}$ & $\begin{array}{c}\text { Rainfall } \\
(\mathrm{mm}))^{* *}\end{array}$ \\
\hline AQ10 & \multirow{2}{*}{ Pantanal } & Dystrophic Red & \multirow{2}{*}{ Aw } & 28.1 & 398.1 \\
AQ11 & Yellow argisol & & 28.7 & 315.1 \\
AQ12 & & & 27.9 & 377.9 \\
DS10 & \multirow{2}{*}{ Atlantic } & Haplorthox & Cwa & 25.6 & 200.1 \\
DS11 & Forest & & & 25.9 & 435.5 \\
DS12 & & \multirow{2}{*}{ Aw } & 26.2 & 387.4 \\
CS10 & \multirow{2}{*}{ Cerrado } & Clayey Hapludox & Aw & 26.3 & 214.8 \\
CS11 & & & & & \\
\hline
\end{tabular}

*According to Köppen-Geiger; **During the experiment.

We used the randomized complete block design with 20 genotypes (MNCO1-649F-1-3, MNCO1-649F-2-1, MNCO1-649F-2-11, MNCO2675-4-9, MNCO2-675F-9-5, MNCO2-676F-1, MNCO2-677F-2, MNCO2-677F-5, MNCO2-680F1-2, MNCO2-689F-2-8, MNCO2-701F-2, MNCO3736F-2, MNCO3-736F-6, MNCO3-761F-1, Pingo de Ouro-1-2, BRS-Xiquexique, BRS-Juruá, BRSAracê, BRS-Gurguéia and BRS-Marataoã) and four repetitions. The experimental plot consisted of four rows with five meters long, considering as useful area the two central lines. The genotypes used are coming from the Embrapa Meio-Norte, with fourteen advanced lines and 6 cultivars.

In Aquidauana and Chapadão do Sul mechanized tillage was performed with opening of the grooves for incorporating the fertilizer and seeds, while in Dourados was performed direct sowing (no-tillage) and sowing fertilization consisted applying $200 \mathrm{~kg} \mathrm{ha}^{-1}$ of NPK (04-20-20). At 15 days after sowing, it was performed the thinned to eight plants per meter. Pest control was carried out with application of Delthametrin and Methamidophos insecticides at $60 \mathrm{ml} \mathrm{ha}^{-1}$ and $1 \mathrm{~L}$ $\mathrm{ha}^{-1}$, respectively.

Grain yield data were subjected to individual analysis of variance, having considered the treatment effects such as fixed and the other effects as random. We detected that the relationship between the highest and the lowest mean square of the individual analysis of variance of the residue exceeded the ratio $7: 1$, being performed, thus, the adjustment of the degrees of freedom for the joint analysis of trials (COCHRAN, 1954). Subsequently, the data were submitted to the adaptability and stability analysis using the Eberhart and Russel (1966) and GGE Biplot methods (YAN et al., 2000).

Eberhart and Russel's (1966) linear regression model was $Y_{i j}=m_{i}+b_{i} I_{j}+d_{i j}+e_{i j}$, wherein $Y_{i j}$ is the mean observed of the genotype $i$ in the environment $j ; m_{i}$ is the overall mean of the genotype $i$; $b_{i}$ is the coefficient of regression of the genotype $i ; I_{j}$ is the environmental index $\mathrm{j} ; \mathrm{d}_{\mathrm{ij}}$ is the regression deviation of the genotype $\mathrm{i}$ in the environment $\mathrm{j} ; \mathrm{e}_{\mathrm{ij}}$ is the average error associated to mean. Environmental index was estimated according to the equation $I_{j}=\bar{Y}_{j}-\bar{Y}_{m}$, with $\sum_{j=1}^{n} I_{j}=0$, wherein $\bar{Y}_{m}$ is the overall mean; $\bar{Y}_{j}$ is the mean of the environment $j ; n$ is the number of environments.

According to Eberhart and Russel (1966) method, genotype adaptability was measured by the parameter $\beta_{\mathrm{li}}$, while that the behavior stability was evaluated by the variance of the regression deviations $\left(\sigma_{\text {di }}^{2}\right)$ and of coefficient of determination $\left(R^{2}\right)$ that, according to Cruz et al. (2012), is an auxiliary measure for evaluating the stability. When the $\sigma_{\mathrm{di}}^{2}$ is significant and $\mathrm{R}^{2}$ is higher than $80 \%, \mathrm{R}^{2}$ indicates acceptable predictability. $\mathrm{F}$ test was used to assess the significance of the parameter $\sigma_{\text {di }}^{2}$ while t-test was employed for assessing the significance of the parameter $\beta_{1 \mathrm{i}}$ from Eberhart and Russel (1966) method. This analysis was performed with the assistance of the Genes software (CRUZ, 2013).

GGE Biplot model used was the following: $\mathrm{Y}_{\mathrm{ij}}-\mathrm{y}_{\mathrm{j}}=\mathrm{y}_{1} \varepsilon_{\mathrm{i} 1} \rho_{\mathrm{j} 1}+\mathrm{y}_{2} \varepsilon_{\mathrm{i} 2} \rho_{\mathrm{j} 2}+\varepsilon_{\mathrm{ij}}$ where: $\mathrm{y}_{\mathrm{ij}}$ represents the average grain yield of the population of $i$ order in the in the environment of $j$ order; $y_{j}$ is the overall mean of the genotypes into environment $\mathrm{j} ; \mathrm{y}_{1} \varepsilon_{\mathrm{i} 1} \rho_{\mathrm{j} 1}$ is the first principal component (PC1); $\mathrm{y}_{2} \varepsilon_{\mathrm{i} 2} \rho_{\mathrm{j} 2}$ is the second principal component (PC2); $\mathrm{y}_{1}$ and $\mathrm{y}_{2}$ are the eigenvalues associated with IPCA1 and IPCA2, respectively; $\varepsilon_{1}$ and $\varepsilon_{2}$ are PC1 and PC2 values, respectively, for the genotype of $\mathrm{i}$ order; $\rho_{\mathrm{j} 1}$ and $\rho_{\mathrm{j} 2}$ are $\mathrm{PC} 1$ and $\mathrm{PC} 2$ values, respectively, for the environment of $\mathrm{j}$ order; and $\varepsilon_{\mathrm{ij}}$ is the error associated with the $\mathrm{i}$-th genotype and $\mathrm{j}$-th environment model 
(YAN et al. 2000). This analysis was performed using the $\mathrm{R}$ software (R DEVELOPMENT CORE TEAM, 2014).

\section{RESULTS AND DISCUSSION}

In joint analysis (Table 2), all effects were significant $(\mathrm{P} \leq 0.05)$, which indicates contrasts between environments and the occurrence of differential genotypes response against the environmental effects. Similar results were obtained by Rocha et al. (2007),
Barros et al. (2013), Nunes et al. (2014), Teodoro et al. (2015), Santos et al. $(2015,2016)$ who also found significant differences in the genotype, environments and genotypes $\mathrm{x}$ environments interaction effects, evaluating semi-prostate cowpea genotypes in multienvironments trials in the Mid-North and Midwest Brazilian region. The existence of significant genotypes $\mathrm{x}$ environments interaction for grain yield indicates that the adaptability and stability analyzes are appropriate because the edaphoclimatic factors are those that most influence the adaptability and stability of genotypes.

Table 2. Summary of analysis of variance related to grain yield $\left(\mathrm{kg} \mathrm{ha}^{-1}\right)$, of 20 upright and semi-prostate cowpea genotypes obtained in 8 environments in the state of Mato Grosso do Sul.

\begin{tabular}{lcc}
\hline Sources of variation & Degrees of freedom $^{(1)}$ & Mean square \\
\hline Environment (E) & 7 & $7,531,617.03^{*}$ \\
Genotype (G) & 19 & $68,657.57^{*}$ \\
G x E & 91 & $82,161.68^{*}$ \\
E/G & 140 & $454,634.44^{*}$ \\
E Linear & 1 & $52,721,319.20$ \\
G x E Linear & 19 & $59,881.44$ \\
Deviation & 120 & $81,581.30$ \\
Residue & 295 & $73,729.13$ \\
\hline Coefficient of variation $(\%)$ & --- & 33.03 \\
Mean & --- & 646.63 \\
\hline$*$ significant at 5\% probability; ${ }^{(1)}$ : values adjusted by COCHRAN (1954) method, due to the heterogeneity of residual QM.
\end{tabular}

Based on Eberhart and Russel (1966) method, the genotypes MNCO1-649F-2-11, MNCO2-675-4-9, MNCO2-675F-9-5 and BRS-Xiquexique were the most suitable for unfavorable environments $\left(\beta_{1 \mathrm{i}}<1\right)$ due to the fact that the yield is higher than the environment average, in addition to having high stability $\left(\sigma_{\mathrm{di}}^{2}\right.$ not significant) and predictability $\left(\mathrm{R}^{2}>80 \%\right)$ (Table 3 ). Regarding the favorable environments $\left(\beta_{\mathrm{li}}>1\right)$, the genotypes MNCO2-701F-2 and BRS-Aracê were the most recommended, since they combine high average yield and stability ( $\sigma^{2}$ di significant and not significant), in addition to having acceptable predictability $\left(\mathrm{R}^{2}>80 \%\right)$ according to Cruz et al. (2012). Barros et al. (2013), when assessing the cultivar BRS Xiquexique with another group of genotypes and environments, found that it has adaptability to unfavorable environments and high predictability, resembling the results obtained in this study.

Table 3. Overall means for yield grain $\left(\beta_{0 \mathrm{i}}, \mathrm{kg} \mathrm{ha}^{-1}\right)$, coeficiente of regression estimates $\left(\beta_{\mathrm{li}}\right)$, deviation of regression $\left(\sigma_{\mathrm{di}}^{2}\right)$ and coefficient of deviation $\left(\mathrm{R}^{2}\right)$, according to Eberhart \& Russell (1966) method in ), of 20 upright and semi-prostate cowpea genotypes obtained in 8 environments in the state of Mato Grosso do Sul.

\begin{tabular}{cccccc}
\hline Identification & Genotype & $\beta_{0 \mathrm{i}}\left(\mathrm{kg} \mathrm{ha}^{-1}\right)$ & $\beta_{1 \mathrm{i}}$ & $\left(\sigma^{2}{ }_{\mathrm{di}}\right)$ & $\mathrm{R}^{2}$ \\
\hline G1 & MNCO1-649F-1-3 & 635.68 & $1.10^{\mathrm{ns}}$ & $-8,699.09^{\mathrm{ns}}$ & 95.55 \\
G2 & MNCO1-649F-2-1 & 632.66 & $0.94^{\mathrm{ns}}$ & $-5,767.04^{\mathrm{ns}}$ & 91.54 \\
G3 & MNCO1-649F-2-11 & 673.31 & $0.99^{\mathrm{ns}}$ & $1,840.43^{\text {ns }}$ & 86.49 \\
G4 & MNCO2-675-4-9 & 683.84 & $0.92^{\mathrm{ns}}$ & $2,342.73^{\text {ns }}$ & 84.46 \\
G5 & MNCO2-675F-9-5 & 671.43 & $0.91^{\text {ns }}$ & $3,510.84^{\text {ns }}$ & 83.12 \\
G6 & MNCO2-676F-1 & 693.38 & $1.19^{\text {ns }}$ & $13,062.40^{\text {ns }}$ & 84.71 \\
G7 & MNCO2-677F-2 & 660.69 & $1.09^{\text {ns }}$ & $4,122.36^{\text {ns }}$ & 87.28 \\
G8 & MNCO2-677F-5 & 582.56 & $0.80^{\text {ns }}$ & $-1,959.66^{\text {ns }}$ & 84.67 \\
G9 & MNCO2-680F-1-2 & 650.12 & $0.95^{\mathrm{ns}}$ & $5,722.67^{7^{\mathrm{ns}}}$ & 82.95
\end{tabular}




\begin{tabular}{lccccc} 
G10 & MNCO2-689F-2-8 & 597.77 & $0.93^{\text {ns }}$ & $-1,045.00^{\text {ns }}$ & 87.28 \\
G11 & MNCO2-701F-2 & 700.43 & $1.32^{*}$ & $-6,985.54^{\text {ns }}$ & 96.05 \\
G12 & MNCO3-736F-2 & 585.62 & $1.23^{*}$ & $35,094.23^{*}$ & 76.79 \\
G13 & MNCO3-736F-6 & 587.87 & $1.16^{\text {ns }}$ & $-7,889.37^{\text {ns }}$ & 95.54 \\
G14 & MNCO3-761F-1 & 639.68 & $0.80^{\text {ns }}$ & $13,407.68^{\text {ns }}$ & 71.58 \\
G15 & Pingo de Ouro-1-2 & 611.51 & $0.90^{\text {ns }}$ & $-2,817.03^{\text {ns }}$ & 88.09 \\
G16 & BRS-Xiquexique & 666.03 & $0.94^{\text {ns }}$ & $-7,851.00^{\text {ns }}$ & 93.31 \\
G17 & BRS-Juruá & 569.92 & $1.08^{\text {ns }}$ & $1,342.99^{\text {ns }}$ & 88.70 \\
G18 & BRS-Aracê & 649.62 & $1.10^{*}$ & $6,649.01^{\text {ns }}$ & 86.18 \\
G19 & BRS-Gurguéia & 734.35 & $0.76^{\text {ns }}$ & $28,569.12^{*}$ & 59.32 \\
G20 & BRS-Marataoã & 706.09 & $0.89^{\text {ns }}$ & $38,625.16^{*}$ & 62.12 \\
\hline
\end{tabular}

*: Significant at $5 \%$ probability, by $\mathrm{F}$ test for the parameter $\sigma_{\mathrm{di}}^{2}$ Gen and by t-test for the parameter $\beta_{1 i}$; ${ }^{\text {ns }}$ : no significant.

Figure 1 shows a polygon that connects the genotypes MNCO3-736F-2 (G12), BRS-Marataoã (G20), BRS-Gurguéia (G19), MNCO3-761F-1 (G14), MNCO2-675F-9-5 (G5) and BRS-Juruá (G17), which are the furthest ones from the biplot origin. These genotypes have the largest vectors in the respective directions; the vector length and direction represents the extension of the genotypes response tested for environments. All of the other genotypes are contained within the polygon and have lower vectors, i.e., they are less sensitive when compared to the interaction with the environments of each sector (YAN; RAJCAN, 2002). Vectors from the biplot center $(0 ; 0)$, perpendicular to the sides of the polygon, divided the graph into six sectors. Likewise, Mattos et al. (2013), Correa et al. (2016) and Santos et al. (2016) assessed the productivity of sugarcane, common bean and cowpea genotypes, respectively, using the GGE Biplot methodology and found that the graphs were divided into six sectors.

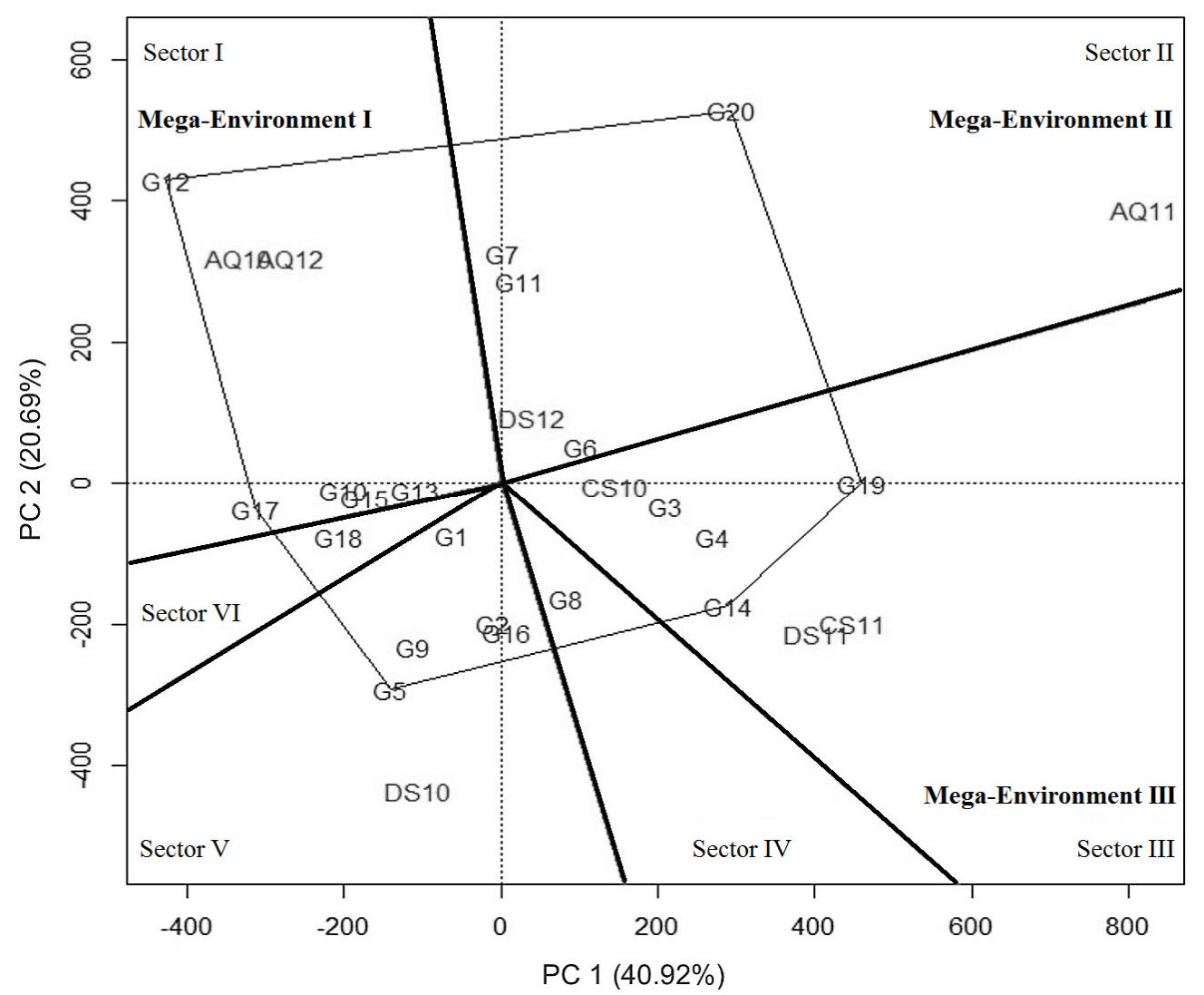

Figure 1. GGE Biplot of the first two principal components (PC1 and PC2) for the average grain yield of 20 upright and semi-prostate cowpea genotypes obtained in 8 environments in the state of Mato Grosso do Sul. 
Biplot GGE polygon (Figure 1) clustered the sites AQ10 and AQ12 into Mega-environment I; AQ11 and DS12 into Mega- environment II; CS10, CS11 and DS11 into Mega- environment III. Megaenvironments are the sectors containing one or more environments. The Genotype MNCO3-736F-2 (G12), present at vertex of the Mega-environment I, had the highest average grain yield in the environments AQ10 and AQ12; BRS-Marataoã (G20) contained into the vertex of the Megaenvironment II achieved the highest yield in AQ11; among the genotypes allocated at the vertices of the Mega-environment III, BRS-Gurguéia (G19) was the most productive in DS11, while MNCO3-761F1 (G14) obtained the better performance in CS10 and CS11.

When genotypes give rise to vertices of the polygon, but do not contain any clustered environment, they are considered unfavorable for the tested environments groups with low yield (MIRANDA et al., 2009). Thus, individuals in
SANTOS, A. et al

sectors included by them are also unfavorable for the recommendation. In this context, except for the cultivar BRS-Aracê (G18, sector VI), it can be inferred that the other genotypes have some specific adaptation and should be evaluated carefully in order to obtain better recommendations (Figure 1).

According to Yan and Rajcan (2002), an ideal genotype should have a average grain yield consistently high in all evaluated environments. This ideal genotype is graphically defined by the longest vector in PC1 and PC2 without projections, represented by the arrow in the center of concentric circles (Figure 2). Although this genotype is more of a representative model, it is used as a reference for the evaluation of the genotype. Thus, the cultivar BRS-Gurguéia (G19), inserted in the second concentric circle and the genotypes MNCO1-649F2-11 (G3) and MNCO2-675-4-9 (G4), both allocated in the third round, are the closest to the ideal in terms of high yield and phenotypic stability.

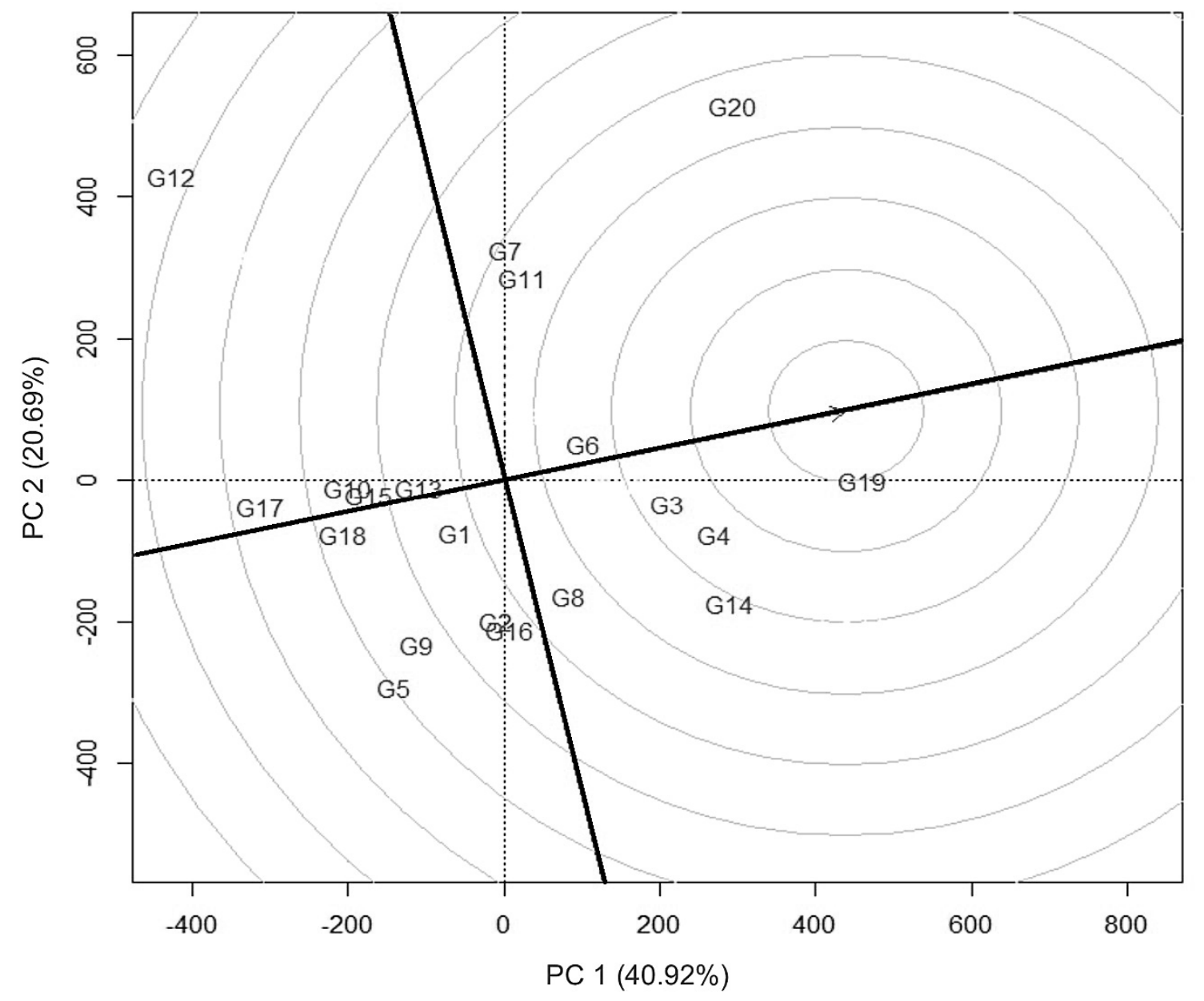

Figure 2. Comparison of 20 cowpea genotypes evaluated in 8 environments of the Mato Grosso do Sul with the ideal genotype by the GGE Biplot methodology.

It is worth mentioning that the cultivar BRS-Gurguéia (G19), despite obtaining a higher average yield over the evaluated environments and be close to the ideal genotype by GGE biplot 
method, obtained significant $\sigma_{\text {di }}^{2}(\mathrm{P} \leq 0.05)$ and low predictability $\left(\mathrm{R}^{2}<60 \%\right)$ by Eberhart and Russel (1966) method. This indicates that this cultivar has adaptability to specific environments and its cultivation cannot be recommended in widespread manner to the state of Mato Grosso do Sul because of its low phenotypic stability.

According to Yan and Rajcan (2002), an ideal environment should have a high score for PC1 (greater power of genotype discrimination in terms of genotype main effects) and zero score for PC2 (greater representation of all other environments). Thus, in Figure 3, This environment is represented on the $\mathrm{x}$-axis by an arrow in the center of concentric circles. In the same way that the ideal genotype, the ideal environment is just an estimation and serves as a reference for selecting a site for multi-testing environments. Therefore, the environments AQ11 (first concentric circle) and CS11 and DS11 (both tirth concentric circle) are those with greater ability to discriminate genotypes, favoring the selection of superior genotypes.

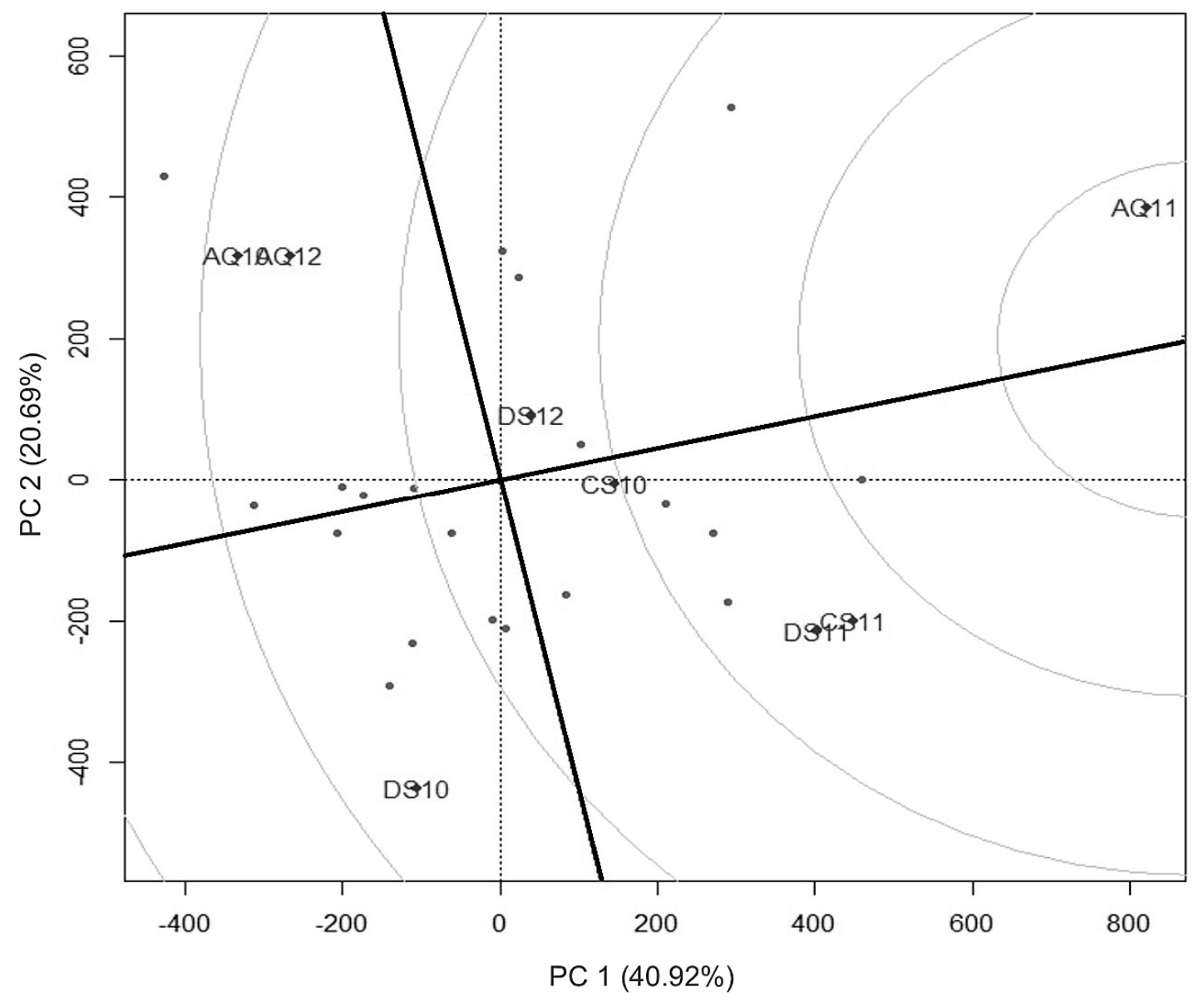

Figure 3. Comparison of 8 environments of the Mato Grosso do Sul with the ideal environment for discrimination of genotypes by the GGE Biplot methodology.

\section{CONCLUSIONS}

Eberhart \& Russell's (1966) and GGE biplot methodologies discriminate differently the best cowpea genotypes and it can be used in a complementary way.
MNCO1-649F-2-11 and MNCO2-675-4-9 genotypes are the closest to the ideal in terms of high grain yield and phenotypic stability, being so suitable for cultivation in the state of Mato Grosso do Sul.

RESUMO: O objetivo deste trabalho foi verificar a associação entre as metodologias de Eberhart \& Russel e GGE Biplot e selecionar genótipos de feijão-caupi que reúnam simultaneamente alta produtividade de grãos, adaptabilidade e estabilidade aos ambientes de Mato Grosso do Sul. Os experimentos foram realizados no período de fevereiro a julho de 2010, 2011 e 2012, nos municípios de Dourados, Aquidauana e Chapadão do Sul. Os experimentos em Chapadão do Sul foram realizados apenas nos anos de 2010 e 2011, totalizando oito ambientes. Após detectar interação da GE significativa, a adaptabilidade e estabilidade fenotípica dos genótipos de feijão-caupi foi analisada pelos métodos GGE Biplot e regressão linear. As metodologias de Eberhart \& Russell e GGE biplot discriminam de forma distinta os melhores 
genótipos de feijão-caupi e podem ser usadas de forma complementar. Os genótipos MNCO1-649F-2-11 e MNCO2-675-4-9 são indicados para o cultivo no Estado de Mato Grosso do Sul, pois aliam alta produtividade de grãos e estabilidade fenotípica.

PALAVRAS-CHAVE: Análise multivariada. Interação genótipo x ambiente. Vigna unguiculata.

\section{REFERÊNCIAS}

BARROS, M. A.; ROCHA, M. M.; GOMES, R. L. F.; SILVA, K. J. D.; NEVES, A. C. Adaptabilidade e estabilidade produtiva de feijão caupi de porte semiprostrado. Pesquisa Agropecuária Brasileira, Brasília, v. 48, p. 403-410, 2013. https://doi.org/10.1590/S0100-204X2013000400008

BARROSO, L. M. A.; TEODORO, P. E.; NASCIMENTO, M.; TORRES, F. E.; SANTOS, A.; CORREA, A. M.; SAGRILO, E.; CORREA, C. C. G.; SILVA, F. A.; CECCON, G. Bayesian approach increases accuracy when selecting cowpea genotypes with high adaptability and phenotypic stability. Genetics and Molecular Research, Ribeirão Preto, v. 15, p. 15017625, 2016. http://dx.doi.org/10.4238/gmr.15017625

COCHRAN, W. G. The combination of estimates from different experiments. Biometrics, Whasington, v. 10, p. 101-129, 1954.

CORREA, A. M.; TEODORO, P. E.; GONCALVES, M. C.; SANTOS, A.; TORRES, F. E. Selection of common bean (Phaseolus vulgaris L.) genotypes using a genotype plus genotype $\mathrm{x}$ environment interaction biplot. Genetics and Molecular Research, Ribeirão Preto, v. 15, p. 1-9, 2016. https://doi.org/10.4238/gmr.15038427

CRUZ, C. D. GENES - a software package for analysis in experimental statistics and quantitative genetics. Acta Scientiarum Agronomy, Maringá, v. 35, p.271-276, 2013.

CRUZ, C. D.; CARNEIRO, P. C. S.; REGAZZI, A. Modelos biométricos aplicados ao melhoramento genético. Viçosa: Editora da UFV, 2012, 514p.

EBERHART, S. A.; RUSSELL, W. A. Stability parameters for comparing varieties. Crop Science, Madson, v. 6, p. 3640, 1966.

MATTOS, P. H. C.; OLIVEIRA, R. A.; BESPALHOK FILHO, C.; DAROS, E.; VERÍSSIMO, M. A. A. Evaluation of sugarcane genotypes and production environments in Paraná by GGE biplot and AMMI analysis. Crop Breeding and Applied Biotechnology, Viçosa, v. 13, p. 83-90, 2013.

MIRANDA, G. V.; SOUZA, L. V.; GUIMARÃES, L. J. M.; NAMORATO, H.; OLIVEIRA, L. R.; SOARES, M.O. Multivariate analyses of genotype $\mathrm{x}$ environment interaction of popcorn. Pesquisa Agropecuária Brasileira, Brasília, v. 44, p. 45-50, 2009. https://doi.org/10.1590/S0100-204X2009000100007

NUNES, H. F.; FREIRE FILHO, F. R.; RIBEIRO, V. Q.; GOMES, R. L. Grain yield adaptability and stability of blackeyed cowpea genotypes under rainfed agriculture in Brasil. African Journal of Agricultural Research, Neirobi, v. 9, p. 255-261, 2014.

R Development Core Team. R: a language and environment for statistical computing. Vienna: R Foundation for Statistical Computing, 2014. Disponible em: <http://www.R-project.org>. Access in 18 jun. 2015.

ROCHA, M. M.; FREIRE-FILHO, F. R.; RIBEIRO, V. Q.; CARVALHO, H. W. L.; BELARMINO-FILHO, J.; RAPOSO, J. A. A.; ALCÂNTARA, J. P.; RAMOS, S. R. R.; MACHADO, C. F; Adaptabilidade e estabilidade produtiva de genótipos de feijão-caupi de porte semiereto na região Nordeste do Brasil. Pesquisa Agropecuária Brasileira, Brasília, v. 42, p. 1283-1289, 2007. https://doi.org/10.1590/S0100204X2007000900010 
SANTOS, J. A. S.; SOARES, C. M. G.; CORRÊA, A. M.; TEODORO, P. E.; RIBEIRO, L. P.; ABREU, H. K. A. Agronomic performance and genetic dissimilarity among cowpea (Vigna unguiculata (L.) Walp.) genotypes. Global Advanced Research Journal of Agricultural Science, New Deli, v. 3, p. 271-277, 2014. SANTOS, A.; CECCON, G.; TEODORO, P. E.; CORREA, A.M.; ALVAREZ, R. C. F.; SILVA, J. F.; ALVES, V. B. Adaptability and stability of erect cowpea genotypes via REML/BLUP and GGE Biplot. Bragantia, Campinas, p. 1-9, 2016.

SANTOS, A.; CECCON, G.; RODRIGUES, E. V.; TEODORO, P. E.; MAKINO, P. A.; ALVES, V. B.; SILVA, J. F.; CORREA, A. M.; ALVAREZ, R. C. F. Adaptability and stability of cowpea genotypes to Brazilian Midwest. African Journal of Agricultural Research, Cidad do Cabo, v. 10, p. 3901-3908, 2015.

TEODORO, P. E.; BARROSO, L. M. A.; NASCIMENTO, M.; TORRES, F.E.; SAGRILO, E.; SANTOS, A.; RIBEIRO, L. P. Redes neurais artificiais para identificar genótipos de feijão-caupi semiprostrado com alta adaptabilidade e estabilidade fenotípicas. Pesquisa Agropecuária Brasileira, Brasília, v. 50, p. 1054-1060, 2015. https://doi.org/10.1590/S0100-204X2015001100008

TORRES, F. E.; TEODORO, P. E.; CARGNELUTTI FILHO, A.; SANTOS, A; ROCHA, M. M.; SAGRILO, E. Adaptability and phenotypic stability of semi-prostate cowpea genotypes in Mato Grosso do Sul. Bioscience Journal (Online), v. 32, p. 1435-1441, 2016.

YAN, W.; HUNT, L. A.; SHENG, Q. L.; SZLAVNICS, Z. Cultivar evaluation and mega-environment investigation based on the GGE Biplot. Crop Science, Madson, v. 40, p. 597-605, 2000.

YAN, W.; RAJCAN, I. Biplot evaluation of test sites and trait relations of soybean in Ontario. Crop Science, Madson, v. 42, p. 11-20, 2202.

YANG, R. C.; HUNT, L. A.; SHENG, Q. L.; SZLAVNICS, Z. Biplot analysis of genotype x environment interaction: proceed with caution. Crop Science, Madson, v. 49, p. 1564-1576, 2009. 